\title{
Peran Pemerintah Daerah Dalam Pemenuhan Hak Orang Dengan Gangguan Jiwa Di Kabupaten Hulu Sungai Utara
}

\author{
Selamat Riadi \\ Program Studi Magister Administrasi Publik, Fakultas Ilmu Sosial dan Ilmu Politik, \\ Universitas Lambung Mangkurat \\ Korespondensi : didymartunis@gmail.com
}

\begin{abstract}
Abstrak
Penelitian ini bertujuan untuk mendeskripsikan : (1) Peran Pemerintah Daerah Kabupaten Hulu Sungai Utara dalam Pemenuhan Hak Orang Gangguan jiwa dan (2) apasaja kendala pada Pemerintah Daerah Kabupaten Hulu Sungai Utara dalam Pemenuhan Hak Orang Gangguan dengan Jiwa. Metode penelitian adalah pendekatan kualitatif dengan teknik purposive sampling. Masalah yang dibahas dalam penelitian ini adalah Peran Pemerintah Daerah dalam pemenuhan hak orang dengan gangguan jiwa yang di latar belakangi tingginya orang dengan gangguan jiwa dirantai dan dipasung. hal ini dikarenakan tidak adanya perhatian Pemerintah yang memberikan pengobatan serta rehabilitasi kepada orang dengan gangguan jiwa tersebut. Regulasi yang Tidak ada menyebabkan tidak ada turunan kebijakan berupa SOP dalam melakukan pelayanan kepada orang dengan gangguan jiwa, Masalah lainnya terletak pada sarana maupun pada fasilitas pendukung lainnya seperti obat-obatan untuk orang dengan gangguan jiwa yang minim, tidak adanya rumah rehabilitasi, Rumah sakit jiwa yang sulit terjangkau serta tidak ada perlindungan dari setiap bentuk penelantaran, kekerasan terhadap orang dengan gangguan jiwa.
\end{abstract}

Kata Kunci: Peran Pemerintah, Orang Dengan Gangguan Jiwa.

\section{Abstrak}

This study aims to describe: (1) The Role of the District Government of Hulu Sungai Utara Regency in Fulfilling the Rights of People with Mental Disorders and (2) what are the obstacles to the Regional Government of Hulu Sungai Utara Regency in Fulfilling the Rights of People with Mental Disorders. The method or approach used in this research is a qualitative approach. The purposive sampling. The problem discussed in this research is the local Government's role in fulfilling people's rights with mental disorders, with the background that there are many people with mental illnesses in chains and shackles. This is due to the lack of attention from the Government in providing treatment and rehabilitation for people with mental disorders. The non-existent regulation causes no policy derivatives in SOPs in delivering services to people with mental illnesses. Other problems lie in the facilities and other supporting facilities such as medicines for people with minimal mental disorders, no rehabilitation house, the mental hospital which is difficult to reach and there is no protection from any form of neglect, violence against people with mental disorders.

Keywords: Role of Government, People with Mental Disorders.

\section{PENDAHULUAN}

Penelitian ini berangkat dari masalah kurang efektifnya peran Pemerintah Daerah Kabupaten Hulu Sungai Utara disebabkan belum adanya regulasi kebijakan Pemerintah tentang hak dengan orang gangguan jiwa. Akibat belum adanya regulasi tersebut sehingga timbul masalah dalam peran atau fungsi pemerintah dalam pemenuhan hak orang dengan gangguan jiwa, sehingga orang dengan ganggun jiwa kasus dirantai dan dipasung cukup tinggi (Sumber: Dinas Kesehatan, 2018). Gangguan jiwa adalah kumpulan dari keadaan-keadaan yang tidak normal, baik yang berhubungan dengan fisik maupun mental. Berdasarkan Undang-Undang Republik Indonesia Nomor 18 Tahun 2014 tentang Kesehatan jiwa, Pemerintah daerah bertanggung jawab atas pemenuhan hak penderita gangguan jiwa, hak yang dimaksud 
tersebut adalah hak untuk mendapatkan pengobatan dan perawatan serta rehabilitasi guna memperoleh kesembuhan seutuhnya agar mereka dapat menjadi manusia produktif secara sosial dan ekonomis.

Berdasarkan Observasi Awal, peran Pemerintah Daerah pada orang dengan gangguan jiwa sangat minim di Kabupaten Hulu Sungai Utara, dimana orang dengan gangguan jiwa tidak diperhatikan serta diberi kelayakan dengan pemenuhannya. Penderita gangguan jiwa tersebar di empat Kecamatan, yakni Haur Gading, Amuntai Selatan, Babirik dan Danau Panggang, dimana orang dengan gangguan jiwa dirantai dan dipasung hal ini dikarenakan tidak adanya perhatian Pemerintah yang memberikan pengobatan serta rehabilitasi kepada orang dengan gangguan jiwa tersebut.

Hak asasi manusia merupakan hak dasar yang dimiliki oleh setiap manusia dan merupakan anugerah dari Tuhan Yang Maha Esa. Negara Republik Indonesia mengakui dan menjunjung tinggi Hak Asasi Manusia karena Hak Asasi Manusia merupakan hak yang secara kodrati melekat dan tidak dapat dipisahkan dari diri manusia. Hak Asasi Manusia harus dilindungi, dihormati dan ditegakan demi peningkatan martabat kemanusiaan, kesejahteraan sosial dan keadilan manusia. Terkait hal tersebut maka Negara Republik Indonesia dalam hal ini Pemerintah Republik Indonesia berkewajiban secara hukum, politik, ekonomi dan sosial untuk melindungi dan melakukan upaya-upaya dalam penegakan Hak Asasi Manusia.

Undang-Undang Dasar Negara Republik Indonesia Tahun 1945 pasal 28I ayat (4) mengamantkan "perlindungan, pemajuan, penegakan dan pemenuhan hak asasi manusia adalah tanggungjawab negara, terutama pemerintah". Dengan demikian maka pemerintah melindungi agar hak asasi seseorang tidak dilanggar oleh orang lain. Memajukanya dengan upaya-upaya yang bertujuan agar Hak Asasi Manusia semakin dihormati dan melakukan penegakan dengan memberikan hukuman kepada orang yang melakukan pelanggaran terhadap Hak Asasi Manusia dengan mengadili dan menjatuhkan hukuman sesuai dengan undang-undang yang berlaku. Pemerintah juga berkewajiban memenuhi hak setiap warga negaranya tanpa diskriminasi dalam segala aspek kehidupan.

Hak atas kesehatan adalah salah satu hak dasar yang dimiliki oleh setiap manusia. Undang-Undang Republik Indonesia Nomor 36 Tahun 2009 Tentang Kesehatan menyatakan bahwa "kesehatan adalah keadaan sehat, baik secara fisik, mental, spritual maupun sosial yang memungkinkan setiap orang untuk hidup produktif secara sosial dan ekonomis". Sedangkan "gangguan jiwa adalah kumpulan dari keadaankeadaan yang tidak normal , baik yang berhubungan dengan fisik maupun mental”

Undang-undang Republik Indonesia Nomor 39 Tahun 1999 Tentang Hak Asasi Manusia Pasal 42 menegaskan bahwa :

Setiap warga Negara yang berusia lanjut, cacat fisik dan atau cacat mental berhak memperoleh perawatan, pendidikan, pelatihan dan bantuan khusus atas biaya Negara, untuk menjamin kehidupan yang layak sesuai dengan martabat kemanusiaanya, meningkatkan rasa percaya diri dan kemampuan berpartisipasi dalam kehidupan bermasyarakat, berbangsa dan bernegara

Penderita gangguan jiwa termasuk kedalam kategori cacat mental, sesuai dengan pernyataan pasal tersebut maka penderita gangguan jiwa dijamin haknya untuk mendapat perawatan dan bantuan khusus atas biaya Negara untuk menjamin kehidupan yang layak sesuai dengan martabat kemanusiaanya. Hal tersebut didukung pula oleh Undang-undang Republik Indonesia Nomor 36 Tahun 2009 tentang Kesehatan Pasal 147 dan 149 menyatakan bahwa Pasal 147 (1) Upaya penyembuhan penderita gangguan kesehatan jiwa merupakan tanggung jawab Pemerintah, pemerintah daerah dan masyarakat. (2) Upaya penyembuhan sebagaimana dimaksud pada ayat (1) dilakukan oleh tenaga kesehatan yang berwenang dan di tempat yang tepat dengan tetap menghormati hak asasi penderita. (3) Untuk merawat penderita gangguan kesehatan jiwa, digunakan fasilitas pelayanan kesehatan khusus yang memenuhi syarat dan yang sesuai dengan ketentuan peraturan perundang-undangan.ayat (2) yang menyatakan bahwa "pemerintah, pemerintah daerah dan masyarakat wajib melakukan pengobatan dan perawatan difasilitas pelayanan kesehatan bagi penderita gangguan jiwa yang terlantar, menggelandang, mengancam 
keselamatan dirinya dan/atau orang lain, dan/atau mengganggu ketertiban dan/atau keamanan umum".

Dari pernyataan Pasal 149 ayat (2) tersebut dapat kita ketahui bahwa pengobatan dan perawatan wajib diberikan kepada penderita gangguan jiwa yang terlantar, menggelandang, mengancam keselamatan dirinya dan/atau orang lain, dan/atau mengganggu ketertiban dan/atau keamanan umum. Dalam pasal tersebut diperjelas pula bahwa yang melakukan pengobatan dan perawatan salah satunya adalah pemerintah daerah. Landasan hukum terkait pemenuhan hak penderita gangguan jiwa juga terdapat pada Undang-Undang Republik Indonesia Nomor 18Tahun 2014 Tentang Kesehatan Jiwa yang memperkuat pernyataan yang ada pada Undang-undang Republik Indonesia Nomor 36 Tahun 2009 Pasal 149 ayat (2).

Undang-Undang Republik Indonesia Nomor 18 Tahun 2014 Tentang Kesehatan Jiwa Pasal 81 menyatakan bahwa :

Pemerintah dan Pemerintah Daerah wajib melakukan upaya rehabilitasi terhadap ODGJ terlantar, menggelandang, mengancam keselamatan dirinya dan/atau orang lain, dan/atau mengganggu ketertiban dan/atau keamanan umum.ODGJ terlantar, menggelandang, mengancam keselamatan dirinya dan/atau orang lain, dan/atau mengganggu ketertiban dan/atau keamanan umum sebagaimana dimaksud pada ayat (1) meliputi ODGJ:Tidak mampu;Tidak mempunyai keluarga, wali atau pengampu; dan/atau tidak diketahui keluarganya Bunyi dari pasal tersebut mendukung pasal 149 ayat (2) dalam UndangundangRepublik Indonesia Nomor 36 Tahun 2009 Tetang Kesehatan. Dengan adanya pasal-pasal yang telah disebutkan dengan jelas sebelumnya maka dapatdisimpulkan bahwa pemerintah daerah bertanggung jawab atas pemenuhan hak penderita gangguan jiwa, hak yang dimaksud tersebut adalah hak untukmendapatkan pengobatan dan perawatan serta rehabilitasi guna memperoleh kesembuhan seutuhnya agar mereka dapat menjadi manusia produktif secara sosial dan ekonomis. Rehabilitasi yang dilakukan untuk kesembuhan penderita ganguan jiwa adalah rehabilitasi sosial.

Surat Menteri Dalam Negeri Nomor :PEM.29/6/15, tanggal 11 Nopember 1977 yang ditujukan kepada Gubernur Daerah Tingkat I seluruh Indonesia meminta kepada masyarakat untuk tidak melakukan pemasungan terdahap penderita gangguan jiwa dan menumbuhkan kesadaran masyarakat untuk menyerahkan perawatan penderita di rumah sakit jiwa. Surat tersebut juga berisikan instruksi untuk para Camat dan kepala desa agar secara aktif mengambil prakarsa dan langkah-langkah dalam penganggulanan pasien yang ada di daerah mereka. Pemerintah daerah bertanggung jawab atas segala fasilitas pelayanan kesehatan jiwa dengan melibatkan peran serta aktif masyarakat, termasuk biaya pengobatan dan perawatan gangguan jiwa untuk masyarakat miskin.

Regulasi yang Tidak ada menyebabkan tidak ada turunan kebijakan berupa SOP dalam melakukan pelayanan kepada orang dengan gangguan jiwa, kalaupun ada pelayanan selama ini ODGJ hanya pada aspek (a) Mendapatkan perhatian Pemerintah pada ODGJ, (b) Mendapatkan jaminan serta ketersediaan obat sesuai dengan kebutuhannya, (c) mendapatkan kebutuhan sosial sesuai dengan tingkat gangguan jiwa, (d) mendapatkan pelayanan kesehatan jiwa di fasilitas pelayanan kesehatan yang mudah di jangkau.

Sebagaimana masalah umum tentang orang dengan gangguan jiwa yang disajikan sebelumnya yaitu sangat banyaknya orang dengan gangguan jiwa yang tidak diperhatikan. Masalah lainnya juga terletak pada sarana maupun pada fasilitas pendukung lainnya seperti obat-obatan untuk orang dengan gangguan jiwa yang minim, tidak adanya rumah rehabilitasi, Rumah sakit jiwa yang sulit terjangkau serta tidak ada perlindungan dari setiap bentuk penelantaran kekerasan untuk orang dengan gangguan jiwa sebagaimana wawancara dengan keluarga orang dengan gangguan jiwa.

"Selama ini kami sangat kesulitan mendapatkan obat karena ketersediaan obat tidak ada serta sulitnya untuk menemui dokter yang menangani ODGJ”. (Sumber : Hasil wawancara dengan keluarga ODGJ, Tanggal 18 Desember 2019).

Dinas Kesehatan Kabupaten Hulu Sungai Utara merupakan perangkat kerja Pemerintah Daerah yang melaksanakan upaya pemenuhan hak penderita gangguan kesehatan jiwa, berdasarkan data dari 
Dinas Kesehatan Kabupaten Hulu Sungai Utara tahun 2018 masalah gangguan jiwa dengan kasus dipasung dan dirantai cukup tinggi. Jumlah semua nya ada 32 orang, yang mana kasus dipasung ( $56 \%$ ) dan kasus dirantai $(22 \%)$.

Berdasarkan data di atas dapat diketahui bahwa orang dengan gangguan jiwa yang dilakukan pemasungan cukup tinggi. Apabila penderita gangguan jiwa dibiarkan begitu saja tanpa ada penanganan khusus maka dapat menjadi penyakit menahun yang sulit untuk disembuhkan. Adanya pemasungan ini memang sebagaimana dipaparkan sebelumnya karena peran Pemerintah kurangnya upaya lain seperti pendidikan kesehatan jiwa, pencegahan atau deteksi dini gangguan jiwa dan pemberdayaan pada masyarakat terhadap penderita gangguan jiwa melalui upaya kegiatan kesadaran, kepedulian serta pemahaman terhadap masalah kesehatan jiwa warganya serta tidak memperhatikan orang dengan gangguan jiwa berkeliaran yang dapat membahayakan dirinya sendiri dan orang lain, sehingga orang dengan gangguan jiwa tersebut di pasung.Berangkat dari fenomena tersebut, maka peneliti tertarik untuk melakukan penelitian Peran Pemerintah Daerah Dalam Pemenuhan Hak Orang Dengan Gangguan Jiwa Di Kabupaten Hulu Sungai Utara".

\section{METODE}

Jenis Penelitian yang digunakan dalam penelitian ini adalah jenis Kualitatif. Diharapkan dengan jenis ini akan ditemukan makna yang tersembunyi dibalik obyek maupun subjek yang akan diteliti. jenis penelitian Kualitatif sebagai suatu konsep keseluruhan berupaya untuk mengungkapkan rahasia sesuatu, dilakukan dengan menghimpun informasi dalam keadaan sewajarnya. Mempergunakan cara kerja yang sistematik, terarah dan dapat dipertanggung jawabkan secara kualitatif. Sehingga tidak kehilangan sifat ilmiahnya. Artinya penelitian ini tidak hanya merekam hal-hal yang nampak secara eksplisit saja, melainkan meliat secara keseluruhan fenomena yang terjadi dalam masyarakat ( Nawawi, 1994:75). Penelitian Kualitatif adalah prosedur penelitian yang menghasilkan data deskriptif berupa kata-kata tertulis atau lisan dari orang.orang yang diamati (Moleong,2007).Lokasi Penelitian ini adalah seputar wilayah Kabupaten Hulu Sungai Utara dimana orang dengan gangguan jiwanya relatif tinggi dan ada beberapa kasus orang dengan gangguan jiwa di kurung dan dipasung.

\section{HASIL DAN PEMBAHASAN}

Undang-undang Republik Indonesia Nomor 36 Tahun 2009 tentang Kesehatan Pasal 149 ayat (2) yang menyatakan bahwa "pemerintah, pemerintah daerah dan masyarakat wajib melakukan pengobatan dan perawatan difasilitas pelayanan kesehatan bagi penderita gangguan jiwa yang terlantar, menggelandang, mengancam keselamatan dirinya dan/atau orang lain, dan/atau mengganggu ketertiban dan/atau keamanan umum".

Dari pernyataan Pasal 149 ayat (2) tersebut dapat kita ketahui bahwa pengobatan dan perawatan wajib diberikan kepada penderita gangguan jiwa yang terlantar, menggelandang, mengancam keselamatan dirinya dan/atau orang lain, dan/atau mengganggu ketertiban dan/atau keamanan umum. Dalam pasal tersebut diperjelas pula bahwa yang melakukan pengobatan dan perawatan salah satunya adalah pemerintah daerah. Landasan hukum terkait pemenuhan hak penderita gangguan jiwa juga terdapat pada Undang-Undang Republik Indonesia Nomor 18 Tahun 2014 Tentang Kesehatan Jiwa yang memperkuat pernyataan yang ada pada Undang-undang Republik Indonesia Nomor 36 Tahun 2009 Pasal 149 ayat (2).Undang-Undang Republik Indonesia Nomor 18 Tahun 2014 Tentang Kesehatan Jiwa Pasal 81 menyatakan bahwa : 
Pemerintah dan Pemerintah Daerah wajib melakukan upaya rehabilitasi terhadap ODGJ terlantar, menggelandang, mengancam keselamatan dirinya dan/atau orang lain, dan/atau mengganggu ketertiban dan/atau keamanan umum. ODGJ terlantar, menggelandang, mengancam keselamatan dirinya dan/atau orang lain, dan/atau mengganggu ketertiban dan/atau keamanan umum sebagaimana dimaksud pada ayat (1) meliputi ODGJ:tidak mampu;tidak mempunyai keluarga, wali atau pengampu; dan/atau tidak diketahui keluarganya Bunyi dari pasal tersebut mendukung pasal 149 ayat (2) dalam Undang-undang Republik Indonesia Nomor 36 Tahun 2009 Tentang Kesehatan. Dengan adanya pasal-pasal yang telah disebutkan dengan jelas sebelumnya maka dapat disimpulkan bahwa pemerintah daerah bertanggung jawab atas pemenuhan hak penderita gangguan jiwa, hak yang dimaksud tersebut adalah hak untuk mendapatkan pengobatan dan perawatan serta rehabilitasi guna memperoleh kesembuhan seutuhnya agar mereka dapat menjadi manusia produktif secara sosial dan ekonomis. Rehabilitasi yang dilakukan untuk kesembuhan penderita ganguan jiwa adalah rehabilitasi sosial.

Peran Pemerintah lebih sebagai pelayan masyarakat (customer driven government) yang tidak bertujuan memperoleh keuntungan atau profit, sehingga haruslah meeting needs of the customer, not the bureaucracy (Gaebler dalam Labolo, 2017:40), dimana lebih mementingkan tepenuhinya kepuasan pelanggan (customer) dan bukan memenuhi apa yang menjadi kemauan birokrasi itu sendiri.

Dibandingkan dengan rasyid dalam labolo (2017:37) bahwa secara umum peran atau fungsi pemerintah berkenaan dengan fungsi pengaturan (regulation), pelayanan (public service), pemberdayaan (empowering) dan pembangunan (development).

Pengaturan (regulation)

Pelaksanaan peran pemerintah sebagai pengaturan yang lazim dikenal sebagai fungsi regulasi dengan segala bentuknya dimaksudkan sebagai usaha untuk menciptakan kondisi yang tepat sehingga menjadi kondusif bagi berlangsungnya berbagai aktivitas, termasuk terciptanya tatanan sosial yang baik di berbagai kehidupan masyarakat. Sebagai regulator, pemerintah memberikan acuan dasar yang selanjutnya diterjemahkan oleh masyarakat sebagai instrumen untuk mengatur setiap kegiatan pelaksanaan pemberdayaan di masyarakat.

\section{Peraturan Perundang-undangan}

Keinginan untuk menciptakan kebijakan hukum yang lebih baik harus diimbangi dengan usaha untuk mewujudkan peraturan- peraturan yang baik sesuai dengan keadaan dan situasi pada suatu waktu. Kebijakan dari negara melalui badan-badan yang berwenang untuk menetapkan peraturanperaturan yang dikehendaki yang diperkirakan bisa digunakan untuk mengekspresikan apa yang terkandung dalam masyarakat dan untuk mencapai apa yang dicita-citakan. Disadari bahwa sejatinya hukum itu adalah produk kebijakan tapi sebaliknya setelah hukum itu terbentuk kebijakan yang dihasilkan harus sesuai dengan hukum-atau aturan yang berlaku. Sebaik-baiknya produk hukum yang dibuat akan tidak efektif kalau tidak dijalankan oleh birokrat dalam tatanan birokrasi yang baik begitupun sebaliknya birokrat akan menjadi tidak baik kalau tidak ada aturan hukum yang baik.

Dalam hal ini Undang-Undang tentang Kesehatan Jiwa dimaksudkan untuk menjamin setiap orang dapat mencapai kualitas hidup yang baik, menikmati kehidupan kejiwaan yang sehat, bebas dari ketakutan, tekanan, dan gangguan lain yang dapat mengganggu Kesehatan Jiwa; menjamin setiap orang dapat mengembangkan potensi kecerdasan; memberikan pelindungan dan menjamin pelayanan Kesehatan Jiwa bagi ODMK dan ODGJ berdasarkan hak asasi manusia; memberikan pelayanan kesehatan secara terintegrasi, komprehensif, dan berkesinambungan melalui upaya promotif, preventif, kuratif, dan rehabilitatif; menjamin ketersediaan dan keterjangkauan sumber daya dalam Upaya Kesehatan Jiwa; meningkatkan mutu Upaya Kesehatan Jiwa sesuai dengan perkembangan ilmu pengetahuan dan teknologi; dan memberikan kesempatan kepada ODMK dan ODGJ untuk dapat melaksanakan hak dan kewajibannya sebagai Warga Negara Indonesia. 
Berdasarkan hasil wawancara diatas dapat disimpulkan bahwa peran pemerintah dalam pemenuhan hak dengan gangguan jiwa dalam indikator penyedian peraturan perundang-undangan dapat dikatakan sudah baik. Hal ini dapat dilihat dengan adanya Undang-Undang Nomor 18 tahun 2014 tentang kesehatan jiwa yang menjamin pelayanan kesehatan terhadap ODGJ dan peraturan menteri kesehatan nomor 54 tahun 2017 tentang penanggulangan pemasungan pada orang dengan gangguan jiwa.

Berdasarkan hasil observasi yang peneliti lakukan, yaitu dengan melihat dan mengamati keadaan puskesmas di Kabupaten Hulu Sungai Utara dapat disimpulkan bahwa peran pemerintah dalam pemenuhan hak dengan gangguan jiwa dalam indikator penyedian peraturan perundang-undangan dapat dikatakan sudah baik. Hal ini dapat dilihat dari layanan-layanan yang mereka berikan kepada keluarga pasien dengan masalah kesehatan jiwa dengan memberikan obat-obatan, sosialisasi, kunjungan ke rumah pasien sesuai dengan Standar Operasinal Prosedur dalam Undang-Undang Nomor 18 tahun 2014 tentang kesehatan jiwa yang menjamin pelayanan kesehatan terhadap ODGJ dan peraturan menteri kesehatan nomor 54 tahun 2017 tentang penanggulangan pemasungan pada orang dengan gangguan jiwa.

Berdasarkan hasil dokumentasi, yaitu dengan mempelajari dan menelaah aturan-aturan terkait Pemenuhan hak dengan orang gangguan jiwa bisa disimpulkan bahwa peran pemerintah dalam pemenuhan hak dengan gangguan jiwa dalam indikator penyedian peraturan perundang-undangan dapat dikatakan sudah baik. Pemenuhan hak ODGJ tertuang dalam Undang-Undang Nomor 18 tahun 2014 pasal 4 ayat (1) yang menyatakan bahwa Upaya Kesehatan Jiwa dilakukan melalui kegiatan Promotif, Preventif, Kuratif dan Rehabilitatif. Selain itu juga tertuang dalam peraturan menteri kesehatan nomor 54 tahun 2017 tentang penanggulangan pemasungan pada orang dengan gangguan jiwa pada pasal 4 ayat 1 bahwa penanggulangan pemasungan dilakukan melalui pencegahan pamasungan, penanganan pemasungan dan rehabilitasi.

Berdasarkan hasil wawancara, observasi dan dokumentasi, dapat disimpulkan bahwa peran pemerintah dalam pemenuhan hak dengan gangguan jiwa dalam indikator penyedian peraturan perundang-undangan dapat dikatakan sudah baik. Hal ini dapat dilihat dengan adanya Undang-Undang Nomor 18 tahun 2014 tentang kesehatan jiwa yang menjamin pelayanan kesehatan terhadap ODGJ dan peraturan menteri kesehatan nomor 54 tahun 2017 tentang penanggulangan pemasungan pada orang dengan gangguan jiwa. Upaya Kesehatan Jiwa dilakukan melalui kegiatan Promotif, Preventif, Kuratif dan Rehabilitatif dan penanggulangan pemasungan dilakukan melalui pencegahan pamasungan, penanganan pemasungan dan rehabilitasi.

Hal ini sesuai dengan teori rasyid dalam labolo (2017:37) bahwa secara umum peran atau fungsi pemerintah berkenaan dengan fungsi pengaturan (regulation), pelayanan (public service), pemberdayaan (empowering) dan pembangunan (development). Sebagai regulator, pemerintah memberikan acuan dasar yang selanjutnya diterjemahkan oleh masyarakat sebagai instrumen untuk mengatur setiap kegiatan pelaksanaan pemberdayaan di masyarakat.

\section{Peraturan Bupati / Daerah}

Penyerahan sebagian besar kewenangan pemerintahan kepada pemerintah daerah, telah menempatkan pemerintah daerah sebagai ujung tombak pembangunan nasional, dalam rangka menciptakan kemakmuran rakyat secara adil dan merata. Dalam kaitan ini peran dan dukungan daerah dalam rangka pelaksanaan PUU sangat strategis, khususnya dalam membuat peraturan daerah (Perda) dan peraturan daerah lainnya sesuai dengan ketentuan peraturan perundang-undangan.

Pasal 18 ayat (6) UUD 1945 menyatakan bahwa pemerintah daerah berhak menetapkan peraturan daerah dan peraturan-peraturan lain untuk melaksanakan otonomi daerah dan tugas pembantuan. Dalam kaitan ini maka sistem hukum nasional memberikan kewenangan atributif kepada daerah untuk 
menetapkan Perda dan peraturan daerah lainnya, dan Perda diharapkan dapat mendukung secara sinergis program-program Pemerintah di daerah.

Berdasarkan hasil penelitian dapat disimpulkan bahwa peran pemerintah dalam pemenuhan hak dengan gangguan jiwa dalam indikator penyedian peraturan daerah / peraturan bupati dapat dikatakan belum baik. Hal ini dapat dilihat dengan belum adanya Peraturan Daerah atau Peraturan Bupati dalam menindaklanjuti Undang-Undang Nomor 18 tahun 2014 tentang kesehatan jiwa yang menjamin pelayanan kesehatan terhadap ODGJ dan peraturan menteri kesehatan nomor 54 tahun 2017 tentang penanggulangan pemasungan pada orang dengan gangguan jiwa. Walaupun sudah ada dibentuk TIM Pelaksana Kesehatan Jiwa Masyarakat Kabupaten Hulu Sungai Utara pada akhir tahun 2019.

Berdasarkan hasil observasi yang peneliti lakukan, yaitu dengan melihat dan mengamati keadaan puskesmas pada kecamatan di Kabupaten Hulu Sungai Utara adanya kegiatan kunjungan dan sosialisasi dan pembinaan terhadap keluarga ODGJ serta selalu melakukan koordinasi kepada pihak kecamatan dan TIM Pelaksana Kesehatan Jiwa Masyarakat Kabupaten Hulu Sungai Utara.

Berdasarkan hasil dokumentasi, yaitu dengan mempelajari dan menelaah aturan-aturan terkait Pemenuhan hak dengan orang gangguan jiwa bisa disimpulkan bahwa peran pemerintah dalam pemenuhan hak dengan gangguan jiwa dalam indikator penyedian peraturan daerah / peraturan bupati dapat dikatakan belum baik. Hal ini disebabkan karena ketidaksesuain antara fakta dilapangan dengan apa yang diamanahkan dalam Peraturan Menteri Kesehatan nomor 54 tahun 2017 tentang penanggulangan pemasungan pada orang dengan gangguan jiwa pada pasal 11 ayat a bahwa :

“Dalam Penyelenggaraan Penanggulangan Pemasungan pada ODGJ Pemerintah Daerah kabupaten/kota memiliki tugas dan wewenang sebagai berikut: a. menetapkan kebijakan pelaksanaan Penanggulangan Pemasungan ODGJ dengan mengacu pada Peraturan Menteri ini."

Berdasarkan hasil wawancara, observasi dan dokumentasi, dapat disimpulkan bahwa peran pemerintah dalam pemenuhan hak dengan gangguan jiwa dalam indikator penyedian peraturan daerah / peraturan bupati dapat dikatakan belum baik. Hal ini dapat dilihat dengan belum adanya Peraturan Daerah atau Peraturan Bupati dalam menindaklanjuti Undang-Undang Nomor 18 tahun 2014 tentang kesehatan jiwa yang menjamin pelayanan kesehatan terhadap ODGJ dan peraturan menteri kesehatan nomor 54 tahun 2017 tentang penanggulangan pemasungan pada orang dengan gangguan jiwa. Walaupun sudah ada dibentuk TIM Pelaksana Kesehatan Jiwa Masyarakat Kabupaten Hulu Sungai Utara pada akhir tahun 2019, tetapi belum ada Peraturan Daerah yang dibuat terkait pelaksanaan teknis pelayanan kesehatan terhadap ODGJ, sehingga berdampak pada penyediaan fasilitas dan penganggaran untuk pelayanan itu sendiri.

Hal ini tidak sesuai dengan teori rasyid dalam labolo (2017:37) bahwa secara umum peran atau fungsi pemerintah berkenaan dengan fungsi pengaturan (regulation), pelayanan (public service), pemberdayaan (empowering) dan pembangunan (development). Sebagai regulator, pemerintah memberikan acuan dasar yang selanjutnya diterjemahkan oleh masyarakat sebagai instrumen untuk mengatur setiap kegiatan pelaksanaan pemberdayaan di masyarakat.

\section{Pelayanan (public service)}

Berhubungan dengan peran pemerintah sebagai public service, bahwa pemerintah tidaklah diadakan untuk melayani dirinya sendiri, tetapi untuk melayani masyarakat, menciptakan kondisi yang memungkinkan setiap anggota masyarakat mengembangkan kemampuan dan kreativitasnya demi mencapai kemajuan bersama.

Rehabilitasi

Rehabilitasi adalah bagian dari rangkaian proses terapi untuk pemulihan ODGJ melalui pendekatan secara fisik, psikologis dan sosial. Rehabiltisi ditujukan untuk mencegah terjadinya kembali praktik Pemasungan pada ODGJ dan pemberdayaan ODGJ dalam proses reintegrasi ke masyarakat serta 
peningkatan kualitas hidup.

Berdasarkan hasil penelitian disimpulkan bahwa peran pemerintah dalam pemenuhan hak dengan gangguan jiwa dalam indikator pelayanan dalam hal rehabilitasi dapat dikatakan cukup baik. Hal ini dapat dilihat karena usaha yang dilakukan pihak Pemerintah Daerah sudah maksimal meliputi kunjungan, sosialisasi dan penyuluhan yang selalu diberikan kepada keluarga pasien ODGJ walaupun masih terbatas dari segi fasilitas dan Sumber Daya Manusia dikarenakan belum adanya Peraturan Bupati atau Peraturan Daerah sehingga belum ada alokasi dana khusus dari APBD.

Berdasarkan hasil observasi yang peneliti lakukan, yaitu dengan melihat dan mengamati keadaan puskesmas dan Rumah Sakit di Kabupaten Hulu Sungai Utara dapat disimpulkan bahwa peran pemerintah dalam pemenuhan hak dengan gangguan jiwa dalam indikator pelayanan dalam hal rehabilitasi dapat dikatakan cukup baik. Hal ini dapat dilihat dengan adanya kegiatan kunjungan rutin dan sosialisasi dan pembinaan terhadap keluarga ODGJ. Selain itu sudah tersedia ruang khusus untuk penanganan gangguan jiwa di Rumah Sakit Pambalah Batung Amuntai, walaupun dokter yang tersedia hanya 1 orang dan perawat 6 orang.

Berdasarkan hasil dokumentasi, yaitu dengan mempelajari dan menelaah aturan-aturan terkait Pemenuhan hak dengan orang gangguan jiwa bisa disimpulkan bahwa peran pemerintah dalam pemenuhan hak dengan gangguan jiwa dalam indikator Pelayanan dalam hal Rehabilitasi dapat dikatakan belum baik. Hal ini disebabkan karena Pemerintah Daerah Kabupaten Hulu Sungai Utara belum mengupayakan secara maksimal amanat dari Peraturan Menteri Kesehatan Rahibilitasi Penanggulangan pemasungan yang tertuang dalam Pasal 7 ayat (2) bahwa Rehabilitasi dilakukan melalui kegiatan : (1) Advokasi dan edukasi; (2) Fasilitasi kepersetaan jaminan kesehatan; (3) Penyediaan akses kelayanan kesehatan termasuk jaminan keberlanjutan terapi baik fisik maupun jiwa; (4) tatalaksana untuk mengontrol gejela melalui terapi medikasi dan non medikasi; (5) Kunjungan rumah atau layanan rumah; (6) Rehabilitasi Vokasional dan Okuposional; (7) Fasilitasi ODGJ dalam memiliki modal usaha mandiri atau lapangan pekerjaan; (8) Pengembangan Layanan ditempat kediaman termasuk layanan rawat harian; (9) Pengembangan kelompok bantu diri serta organisasi konsumen dan keluarga; (10) fasilitasi proses kembali ke keluarga dan masyarakat.

Berdasarkan hasil wawancara, observasi dan dokumentasi, dapat disimpulkan bahwa peran pemerintah dalam pemenuhan hak dengan gangguan jiwa dalam indikator pelayanan dalam rehabilitasi dapat dikatakan belum baik. Hal ini dapat dilihat dari masih terbatasnya fasilitas dan Sumber Daya Manusia dikarenakan belum adanya Peraturan Bupati atau Peraturan Daerah sehingga belum ada alokasi dana khusus dari APBD walaupun usaha yang dilakukan pihak Pemerintah Daerah sudah maksimal meliputi kunjungan, sosialisasi dan penyuluhan yang selalu diberikan kepada keluarga pasien ODGJ. Selain itu sudah tersedia ruang khusus untuk penanganan gangguan jiwa di Rumah Sakit Pambalah Batung Amuntai, walaupun dokter yang tersedia hanya 1 orang dan perawat 6 orang. Serta belum bisa menerapkan amanat dari Peraturan Menteri Kesehatan tentang Penanggulangan pemasungan yang tertuang dalam Pasal 7 ayat (2) bahwa Rehabilitasi dilakukan melalui kegiatan : (1) Advokasi dan edukasi; (2) Fasilitasi kepersetaan jaminan kesehatan; (3) Penyediaan akses kelayanan kesehatan termasuk jaminan keberlanjutan terapi baik fisik maupun jiwa; (4) tatalaksana untuk mengontrol gejela melalui terapi medikasi dan non medikasi; (5) Kunjungan rumah atau layanan rumah; (6) Rehabilitasi Vokasional dan Okuposional; (7) Fasilitasi ODGJ dalam memiliki modal usaha mandiri atau lapangan pekerjaan; (8) Pengembangan Layanan ditempat kediaman termasuk layanan rawat harian; (9) Pengembangan kelompok bantu diri serta organisasi konsumen dan keluarga; (10) fasilitasi proses kembali ke keluarga dan masyarakat.

Hal ini tidak sesuai dengan teori rasyid dalam labolo (2017:37) bahwa secara umum peran atau fungsi pemerintah berkenaan dengan fungsi pengaturan (regulation), pelayanan (public service), pemberdayaan (empowering) dan pembangunan (development). Berhubungan dengan peran pemerintah 
sebagai public service, bahwa pemerintah tidaklah diadakan untuk melayani dirinya sendiri, tetapi untuk melayani masyarakat, menciptakan kondisi yang memungkinkan setiap anggota masyarakat mengembangkan kemampuan dan kreativitasnya demi mencapai kemajuan bersama.

\section{Pengurangan Penderita}

Pengurangan Penderita yang dimaksud yaitu bagaimana upaya pemerintah daerah untuk menangani pengurangan orang dengan gangguan jiwa maupun pengurangan ODGJ yang dikurung dan dipasung sehingga Hulu Sungai Utara bebas dari orang dengan gangguan jiwa. peran pemerintah dalam pemenuhan hak dengan gangguan jiwa dalam indikator pelayanan dalam hal pengurangan penderita dapat dikatakan cukup baik. Hal ini dapat dilihat karena usaha yang dilakukan pihak Pemerintah Daerah sudah maksimal meliputi kunjungan, sosialisasi, penyuluhan, rehabilitasi serta pembaharuan data yang dilakukan setiap tahunnya antara Dinas Kesehatan dan Dinas Sosial. Permasalahan yang sering muncul yaitu keluarga pasien yang tidak mau melakukan tahapan-tahapan rehabilitasi karena alasan ekonomi.

Berdasarkan hasil observasi yang peneliti lakukan, yaitu dengan melihat dan mengamati keadaan puskesmas dan Rumah Sakit di Kabupaten Hulu Sungai Utara dapat disimpulkan bahwa peran pemerintah dalam pemenuhan hak dengan gangguan jiwa dalam indikator pelayanan dalam hal pengurangan penderita dapat dikatakan cukup baik. Hal ini dapat dilihat dengan adanya kegiatan kunjungan rutin dan sosialisasi dan pembinaan terhadap keluarga ODGJ oleh puskesmas di kecamatan. Selain itu sudah tersedia ruang khusus untuk penanganan gangguan jiwa di Rumah Sakit Pambalah Batung Amuntai.

Berdasarkan hasil wawancara dan observasi, dapat disimpulkan bahwa peran pemerintah dalam pemenuhan hak dengan gangguan jiwa dalam indikator pengurangan penderita dalam rehabilitasi dapat dikatakan cukup baik. Hal ini dapat dilihat karena usaha yang dilakukan pihak Pemerintah Daerah sudah maksimal meliputi kunjungan, sosialisasi, penyuluhan, rehabilitasi serta pembaharuan data yang dilakukan setiap tahunnya antara Dinas Kesehatan dan Dinas Sosial. Selain itu sudah tersedia ruang khusus untuk penanganan gangguan jiwa di Rumah Sakit Pambalah Batung Amuntai. Permasalahan yang sering muncul terletak pada keluarga pasien yang tidak mau melakukan tahapan-tahapan rehabilitasi karena alasan ekonomi.

. Hal ini sesuai dengan teori rasyid dalam labolo (2017:37) bahwa secara umum peran atau fungsi pemerintah berkenaan dengan fungsi pengaturan (regulation), pelayanan (public service), pemberdayaan (empowering) dan pembangunan (development). Berhubungan dengan peran pemerintah sebagai public service, bahwa pemerintah tidaklah diadakan untuk melayani dirinya sendiri, tetapi untuk melayani masyarakat, menciptakan kondisi yang memungkinkan setiap anggota masyarakat mengembangkan kemampuan dan kreativitasnya demi mencapai kemajuan bersama.

\section{Pembangunan (development).}

Peran pemerintah dalam pembangunan adalah menciptakan kondisi yang kondusif dan kemakmuran dalam masyarakat.. Peran Pemerintah Sebagai pembangunan, pemerintah berusaha menciptakan atau memfasilitasi tersedianya sarana dan prasarana pembangunan seperti gedung pelayanan,pendampingan dan pendanaan atau permodalan.

Penyediaan Sumber Daya Manusia (Tenaga Medis)

Keberhasilan proses implementasi kebijakan sangat tergantung dari kemampuan memanfaatkan sumberdaya yang tersedia, sumber daya yang dimaksud salah satunya adalah sumber daya manusia, sehingga dalam menjalankan kebijakan tentang kesehatan jiwa yang khususnya mengenai hak orang dengan gangguan jiwa dapat dilaksanakan. peran pemerintah dalam pemenuhan hak dengan gangguan jiwa dalam indikator penyediaan Sumber Daya Manusia (Tenaga Medis) dapat dikatakan belum baik. Hal ini dapat dilihat karena pada Dinas Kesehatan Kabupaten Hulu Sungai Utara hanya terdapat 1 (satu) orang doktor spesialis yaitu dr. SRS, dan bertugas di Rumah Sakit Pambalah batung Amuntai. sedangkan 
tenaga medis (dokter dan perawat) di puskesmas tidak mempunyai keahlian khusus terkait penanganan secara langsung orang dengan gangguan jiwa.

Berdasarkan hasil observasi yang peneliti lakukan, yaitu dengan melihat dan mengamati keadaan pasien, puskesmas dan Rumah Sakit di Kabupaten Hulu Sungai Utara dapat disimpulkan bahwa peran pemerintah dalam pemenuhan hak dengan gangguan jiwa dalam indikator penyediaan Sumber Daya Manusia (Tenaga Medis) dapat dikatakan belum baik. Hal ini dapat dilihat karena dokter dan tenaga perawat di Puskesmas di Kabupaten Hulu Sungai Utara tidak berlatar pendidikan ahli jiwa, kebanyakan dokter di puskesmas merupakan doktor umum. Pada Rumah Sakit Pambalah Batung Amuntai sendiri hanya memiliki 1 (satu) dokter Spesialis Jiwa dan 6 (enam) orang perawat khusus untuk ruang Jiwa.

Berdasarkan hasil dokumentasi, yaitu dengan mempelajari dan menelaah aturan-aturan terkait Pemenuhan hak dengan orang gangguan jiwa bisa disimpulkan bahwa peran pemerintah dalam pemenuhan hak dengan gangguan jiwa dalam indikator penyediaan sumber daya manusia dapat dikatakan belum baik. Hal ini disebabkan karena Pemerintah Daerah Kabupaten Hulu Sungai Utara belum mengupayakan secara maksimal amanat dari Undang-Undang tentang Kesehatan jiwa yang tertuang dalam Pasal 41 ayat (1) dan ayat (2) bahwa :

Pemerintah dan Pemerintah Daerah wajib mengatur dan menjamin ketersediaan sumber daya manusia di bidang Kesehatan Jiwa untuk pemerataan penyelenggaraan Upaya Kesehatan Jiwa.

Penempatan dan pendayagunaan sumber daya manusia di bidang Kesehatan Jiwa dilakukan dengan tetap memperhatikan hak sumber daya manusia di bidang Kesehatan Jiwa dan hak masyarakat untuk mendapatkan pelayanan Kesehatan Jiwa yang merata.

Berdasarkan hasil wawancara, observasi dan dokumentasi, dapat disimpulkan bahwa peran pemerintah dalam pemenuhan hak dengan gangguan jiwa dalam indikator penyediaan Sumber Daya Manusia (Tenaga Medis) dapat dikatakan belum baik. Hal ini dapat dilihat karena pada Dinas Kesehatan Kabupaten Hulu Sungai Utara hanya terdapat 1 (satu) orang doktor spesialis yaitu dr. SRS, dan bertugas di Rumah Sakit Pambalah batung Amuntai. sedangkan tenaga medis (dokter dan perawat) di puskesmas tidak mempunyai keahlian khusus terkait penanganan secara langsung orang dengan gangguan jiwa. Kebanyakan dokter di puskesmas merupakan doktor umum. Pada Rumah Sakit Pambalah Batung Amuntai sendiri hanya memiliki 1 (satu) dokter Spesialis Jiwa dan 6 (enam) orang perawat khusus untuk ruang Jiwa.

. Hal ini tidak sesuai dengan teori rasyid dalam labolo (2017:37) bahwa secara umum peran atau fungsi pemerintah berkenaan dengan fungsi pengaturan (regulation), pelayanan (public service), pemberdayaan (empowering) dan pembangunan (development). Berhubungan dengan Peran pemerintah dalam pembangunan adalah menciptakan kondisi yang kondusif dan kemakmuran dalam masyarakat.. Peran Pemerintah Sebagai pembangunan, pemerintah berusaha menciptakan atau memfasilitasi tersedianya sarana dan prasarana pembangunan seperti gedung pelayanan,pendampingan dan pendanaan atau permodalan.

\section{Penyediaan Sarana, Prasarana dan sarana pendukung lainnya}

Keberhasilan proses implementasi kebijakan sangat tergantung dari kemampuan memanfaatkan sumberdaya yang tersedia, sumber daya yang dimaksud salah satunya adalah sarana, prasarana dan sarana pendukung lainnya, yang tersedia sehingga dalam menjalankan kebijakan tentang kesehatan jiwa yang khususnya mengenai hak orang dengan gangguan jiwa dapat dilaksanakan. Dalam pemenuhan hak dengan gangguan jiwa dalam indikator penyediaan Sarana prasarana dan penunjang lainnya dapat dikatakan belum baik. Hal ini dapat dilihat karena belum tersedia sarana prasarana yang memadai baik di Puskesmas, di RSUD Pambalah batung Amuntai maupun Di Kabupaten Hulu Sungai Utara pada umumnya. Seperti belum adanya rumah rehab/perawatan, rumah pelatihan dan fasilitas pelayanan di luar sektor kesehatan dan fasilitas pelayanan berbasis masyarakat seperti praktek psikolog, panti social, rumah 
perlindungan social dan sebagainya karena anggaran yang belum mencukupi. Walaupun di RSUD pambalan Batung Amuntai sudah tersedia Ruang Jiwa untuk menampung 11 orang pasien ODGJ.

Berdasarkan hasil observasi yang peneliti lakukan, yaitu dengan melihat dan mengamati keadaan pasien, puskesmas dan Rumah Sakit di Kabupaten Hulu Sungai Utara dapat disimpulkan bahwa peran pemerintah dalam pemenuhan hak dengan gangguan jiwa dalam indikator penyediaan Sarana prasarana dan penunjang lainnya dapat dikatakan belum baik. Hal ini dapat dilihat sarana prasarana di puskesmas di kabupaten Hulu Sungai utara belum ada ruang penanganan khusus terhadap ODGJ. Di RSUD Pambalah Batung Amuntai sendiri sebagai rumah sakit terbesar di HSU hanya memiliki daya tampung 11 orang. Selain itu di Kabupaten Hulu Sungai utara belum Rumah Rehab, praktik Psikiater, praktek Dokter jiwa, Panti Sosial, panti perlindungan dan sebagainya.

Berdasarkan hasil dokumentasi, yaitu dengan mempelajari dan menelaah aturan-aturan terkait Pemenuhan hak dengan orang gangguan jiwa bisa disimpulkan bahwa peran pemerintah dalam pemenuhan hak dengan gangguan jiwa dalam indikator penyediaan Sarana prasarana dan penunjang lainnya dapat dikatakan belum baik. Hal ini disebabkan karena Pemerintah Daerah Kabupaten Hulu Sungai Utara belum mengupayakan secara maksimal amanat dari Undang-Undang tentang Kesehatan jiwa yang tertuang dalam Pasal 45 yaitu Fasilitas pelayanan di bidang kesehatan jiwa meliputi Fasilitas pelayanan kesehatan dan fasilitas pelayanan di luar sektor kesehatan dan fasilitas pelayanan berbasis masyarakat. Fasilitas pelayanan kesehatan terdiri dari Puskesmas dan jejaring, klinik pratama, dan praktik dokter dengan kompetensi pelayanan Kesehatan Jiwa; rumah sakit umum; rumah sakit jiwa; dan rumah perawatan. Fasilitas pelayanan di luar sektor kesehatan dan fasilitas pelayanan berbasis masyarakat sebagaimana dimaksud dalam Pasal 45 meliputi: praktik psikolog; praktik pekerja sosial; panti sosial; pusat kesejahteraan sosial; pusat rehabilitasi sosial; rumah pelindungan sosial; pesantren/institusi berbasis keagamaan; rumah singgah; dan lembaga kesejahteraan sosial.

Berdasarkan hasil wawancara, observasi dan dokumentasi, dapat disimpulkan bahwa peran pemerintah dalam Sarana prasarana dan penunjang lainnya dapat dikatakan belum baik. Hal ini dapat dilihat karena belum tersedia sarana prasarana yang memadai baik di Puskesmas, di RSUD Pambalah batung Amuntai maupun Di Kabupaten Hulu Sungai Utara pada umumnya. Selain itu Pemerintah Daerah Kabupaten Hulu Sungai Utara belum mengupayakan secara maksimal amanat dari Undang-Undang tentang Kesehatan jiwa yang tertuang dalam Pasal 45 yaitu Fasilitas pelayanan di bidang kesehatan jiwa meliputi Fasilitas pelayanan kesehatan dan fasilitas pelayanan di luar sektor kesehatan dan fasilitas pelayanan berbasis masyarakat. Fasilitas pelayanan kesehatan terdiri dari Puskesmas dan jejaring, klinik pratama, dan praktik dokter dengan kompetensi pelayanan Kesehatan Jiwa; rumah sakit umum; rumah sakit jiwa; dan rumah perawatan. Fasilitas pelayanan di luar sektor kesehatan dan fasilitas pelayanan berbasis masyarakat sebagaimana dimaksud dalam Pasal 45 meliputi: praktik psikolog; praktik pekerja sosial; panti sosial; pusat kesejahteraan sosial; pusat rehabilitasi sosial; rumah pelindungan sosial; pesantren/institusi berbasis keagamaan; rumah singgah; dan lembaga kesejahteraan sosial.

Hal ini tidak sesuai dengan teori rasyid dalam labolo (2017:37) bahwa secara umum peran atau fungsi pemerintah berkenaan dengan fungsi pengaturan (regulation), pelayanan (public service), pemberdayaan (empowering) dan pembangunan (development). Berhubungan dengan Peran pemerintah dalam pembangunan adalah menciptakan kondisi yang kondusif dan kemakmuran dalam masyarakat. Peran Pemerintah Sebagai pembangunan, pemerintah berusaha menciptakan atau memfasilitasi tersedianya sarana dan prasarana pembangunan seperti gedung pelayanan,pendampingan dan pendanaan atau permodalan. 


\section{Kendala-Kendala dalam Pemenuhan Hak Orang dengan Gangguan Jiwa di Kabupaten Hulu Sungai Utara.}

Implementasi merupakan suatu proses yang dinamis, dimana pelaksana kebijakan melakukan suatu aktivitas atau kegiatan, sehingga pada akhirnya akan mendapatkan suatu hasil yang sesuai dengan yang sesuai dengan tujuan atau sasaran kebijakan itu sendiri. Beberapa faktor yang mempengaruhi peran pemerintah dalam pemenuhan hak orang dengan gangguan jiwa di Kabupaten Hulu Sungai Utara tersebut berdasarkan hasil wawancara yang peneliti lakukan.

\section{Sumber Daya}

Diketahui bahwa jumlah staf, fasilitas dan anggaran belum mencukupi dalam menagani permasalahan gangguan jiwa, terdapat 1 orang dokter yang bidang keilmuannya khusus menangani masalah gangguan jiwa, belum terpenuhinya sarana prasarana seperti rumah rehab, dan masih minimnya anggaran pendampingan untuk meningkatkan kesehatan masalah gangguan jiwa, sehingga berkenaan dengan sumber daya belum sepenuhnya berjalan baik.

\section{Lingkungan Ekonomi, Sosial dan Politik}

Kondisi Ekonomi, Sosial dan Politik mempengaruhi implementasi pemenuhan hak orang dengan gangguan sehingga program-program pemerintah akan berjalan apabila, kondisi ekonomi masyarakat kuat, pandangan masyarakat mengenai orang gangguan jiwa, dan dukungan politik atau tekanan yang dilakukan oleh pejabat yang lebih tinggi kepada instansi yang berkaitan dalam tugas dan fungsinya.

\section{KESIMPULAN}

Peran Pemerintah Daerah Kabupaten Hulu Sungai Utara dalam Pemenuham Hak Orang Dengan Gangguan Jiwa (ODGJ) belum baik. Hal ini dapat diklasifikasi dari 6 indikator Peran Pemerintah dalam pemenuhan hak ODGJ menurut teori Ryass Rasyid hanya 2 indikator yang bisa dikatakan Cukup Baik Sedangkan 4 indikator lainnya dapat dikatakan Belum Baik. Indikator-indikator Peran Pemerintah dalam pemenuhan hak ODGJ yang belum baik yaitu : Pertama, dalam Indikator Peran Pemerintah dalam Penyediaan peraturan daerah dikatakan belum baik, karena belum adanya Peraturan Daerah atau Peraturan Bupati dalam menindaklanjuti Undang-Undang Nomor 18 tahun 2014 tentang kesehatan jiwa yang menjamin pelayanan kesehatan terhadap ODGJ dan peraturan menteri kesehatan nomor 54 tahun 2017 tentang penanggulangan pemasungan pada orang dengan gangguan jiwa. Walaupun sudah ada dibentuk TIM Pelaksana Kesehatan Jiwa Masyarakat Kabupaten Hulu Sungai Utara pada akhir tahun 2019, tetapi belum ada Peraturan Daerah yang dibuat terkait pelaksanaan teknis pelayanan kesehatan terhadap ODGJ, sehingga berdampak pada penyediaan fasilitas dan penganggaran untuk pelayanan itu sendiri. Kedua, dalam indikator pelayanan dalam rehabilitasi dapat dikatakan belum baik. Hal ini dapat dilihat dari masih terbatasnya fasilitas dan Sumber Daya Manusia dikarenakan belum adanya Peraturan Bupati atau Peraturan Daerah sehingga belum ada alokasi dana khusus dari APBD walaupun usaha yang dilakukan pihak Pemerintah Daerah sudah maksimal meliputi kunjungan, sosialisasi dan penyuluhan yang selalu diberikan kepada keluarga pasien ODGJ. Serta belum bisa menerapkan amanat dari Peraturan Menteri Kesehatan tentang Penanggulangan pemasungan yang tertuang dalam Pasal 7 ayat (2) bahwa Rehabilitasi dilakukan melalui kegiatan : (1) Advokasi dan edukasi; (2) Fasilitasi kepersetaan jaminan kesehatan; (3) Penyediaan akses kelayanan kesehatan termasuk jaminan keberlanjutan terapi baik fisik maupun jiwa; (4) tatalaksana untuk mengontrol gejela melalui terapi medikasi dan non medikasi; (5) Kunjungan rumah atau layanan rumah; (6) Rehabilitasi Vokasional dan Okuposional; (7) Fasilitasi ODGJ dalam memiliki modal usaha mandiri atau lapangan pekerjaan; (8) Pengembangan Layanan ditempat kediaman termasuk layanan rawat harian; (9) Pengembangan kelompok bantu diri serta organisasi konsumen dan keluarga; (10) fasilitasi proses kembali ke keluarga dan masyarakat. Ketiga, dalam 
pemenuhan hak dengan gangguan jiwa dalam indikator penyediaan Sumber Daya Manusia (Tenaga Medis) dapat dikatakan belum baik. Hal ini dapat dilihat karena pada Dinas Kesehatan Kabupaten Hulu Sungai Utara hanya terdapat 1 (satu) orang doktor spesialis dan bertugas di Rumah Sakit Pambalah batung Amuntai. sedangkan tenaga medis (dokter dan perawat) di puskesmas tidak mempunyai keahlian khusus terkait penanganan secara langsung orang dengan gangguan jiwa. Kebanyakan dokter di puskesmas merupakan doktor umum. Pada Rumah Sakit Pambalah Batung Amuntai sendiri hanya memiliki 1 (satu) dokter Spesialis Jiwa dan 6 (enam) orang perawat khusus untuk ruang Jiwa. Keempat, dalam Sarana prasarana dan penunjang lainnya dapat dikatakan belum baik. Hal ini dapat dilihat karena belum tersedia sarana prasarana yang memadai baik di Puskesmas, di RSUD Pambalah batung Amuntai maupun Di Kabupaten Hulu Sungai Utara pada umumnya. Selain itu Pemerintah Daerah Kabupaten Hulu Sungai Utara belum mengupayakan secara maksimal amanat dari Undang-Undang tentang Kesehatan jiwa yang tertuang dalam Pasal 45 yaitu Fasilitas pelayanan di bidang kesehatan jiwa meliputi Fasilitas pelayanan kesehatan dan fasilitas pelayanan di luar sektor kesehatan dan fasilitas pelayanan berbasis masyarakat. Fasilitas pelayanan kesehatan terdiri dari Puskesmas dan jejaring, klinik pratama, dan praktik dokter dengan kompetensi pelayanan Kesehatan Jiwa; rumah sakit umum; rumah sakit jiwa; dan rumah perawatan. Fasilitas pelayanan di luar sektor kesehatan dan fasilitas pelayanan berbasis masyarakat sebagaimana dimaksud dalam Pasal 45 meliputi: praktik psikolog; praktik pekerja sosial; panti sosial; pusat kesejahteraan sosial; pusat rehabilitasi sosial; rumah pelindungan sosial; pesantren/institusi berbasis keagamaan; rumah singgah; dan lembaga kesejahteraan sosial. Sedangkan Indikator Indikator Peran Pemerintah dalam pemenuhan hak ODGJ yang sudah baik yaitu : Pertama, dalam pemenuhan hak dengan gangguan jiwa dalam indikator penyedian peraturan perundang-undangan dapat dikatakan sudah baik. Hal ini dapat dilihat dengan adanya Undang-Undang Nomor 18 tahun 2014 tentang kesehatan jiwa yang menjamin pelayanan kesehatan terhadap ODGJ dan peraturan menteri kesehatan nomor 54 tahun 2017 tentang penanggulangan pemasungan pada orang dengan gangguan jiwa. Upaya Kesehatan Jiwa dilakukan melalui kegiatan Promotif, Preventif, Kuratif dan Rehabilitatif dan penanggulangan pemasungan dilakukan melalui pencegahan pamasungan, penanganan pemasungan dan rehabilitasi. Kedua, dalam pemenuhan hak dengan gangguan jiwa dalam indikator pengurangan penderita dalam rehabilitasi dapat dikatakan cukup baik. Hal ini dapat dilihat karena usaha yang dilakukan pihak Pemerintah Daerah sudah maksimal meliputi kunjungan, sosialisasi, penyuluhan, rehabilitasi serta pembaharuan data yang dilakukan setiap tahunnya antara Dinas Kesehatan dan Dinas Sosial. Selain itu sudah tersedia ruang khusus untuk penanganan gangguan jiwa di Rumah Sakit Pambalah Batung Amuntai. Permasalahan yang sering muncul terletak pada keluarga pasien yang tidak mau melakukan tahapan-tahapan rehabilitasi karena alasan ekonomi.

Kendala - Kendala dalam Pemenuhan Hak Orang dengan Gangguan Jiwa di Kabupaten Hulu Sungai dipengaruhi oleh beberapa faktor yaitu Sumber daya dan Lingkungan Ekonomi, Sosial dan Politik. Sumber Daya yang dimaksud bahwa jumlah staf, fasilitas dan anggaran belum mencukupi dalam menagani permasalahan gangguan jiwa, terdapat 1 orang dokter yang bidang keilmuannya khusus menangani masalah gangguan jiwa, belum terpenuhinya sarana prasarana seperti rumah rehab, dan masih minimnya anggaran pendampingan untuk meningkatkan kesehatan masalah gangguan jiwa. Faktor Lingkungan ekonomi, Sosial dan politik mempengahuri implementasi pemenuhan hak orang dengan gangguan sehingga program-program pemerintah akan berjalan apabila, kondisi ekonomi masyarakat kuat, pandangan masyarakat mengenai orang gangguan jiwa baik, dan dukungan politik atau tekanan yang dilakukan oleh pejabat yang lebih tinggi kepada instansi yang berkaitan dalam tugas dan fungsinya.

\section{SARAN}

Berdasarkan kesimpulan penelitian, maka dapat diberikan saran sebagai berikut: 
1. Bagi Pemerintah Daerah Kabupaten Hulu Sungai Utara perlu memperhatikan sumber daya dalam pemenuhan hak orang dengan gangguan jiwa, sumber daya yang dimaksud Sumber daya manusia, Sarana Prasarana dan Dana, sehingga kegiatan pelayanan kesehatan gangguan jiwa dapat berjalan dengan maksimal. dan bagi Instansi Terkait yang menjalankan pelayanan kesehatan jiwa perlu melakukan program penyuluhan, sosialisasi yang bertujuan merubah anggapan yang menganggap orang dengan gangguan jiwa selalu dikurung dan dirantai.

2. Bagi Masyarakat perlu mendukung kebijakan Pemerintah dalam pemenuhan Hak Orang dengan gangguan jiwa dengan memberikan kesempatan rehabilisasi dan pengobatan tanpa melanggar hak orang dengan gangguan jiwa dengan merantai maupun mengurung orang dengan gangguan jiwa.

\section{DAFTAR PUSTAKA}

[1] Badan Pusat Statistik Kabupaten Hulu Sungai Utara. 2020. Kabupaten Hulu Sungai Utara Dalam Angka. Hulu Sungai Utara : Badan Pusat Statistik

[2] Hardiansyah, 2018. Kualitas Pelayanan Publik. Yogyakarta: Gava Media

[3] Kartono, Kartini. 2014. Patologi Sosial 3 : Gangguan-gangguan kejiwaan. Jakarta:Raja Grafindo Persada

[4] Keban,T. Yeremias. 2008.Enam Dimensi Strategis Administrasi Publik : Konsep, Reori dan Isu. Gava Media. Yogyakarta

[5] Labolo, Muhadam. 2017. Memahami Ilmu Pemerintahan. Depok. Raja Grafindo Persada

[6] Muhith , Abdul. 2015. Pendidikan keperawatan jiwa. Yogyakarta : Andi

[7] Narbuko,Cholid dan Achmadi,Abu,2007,Metode Penelitian, Jakarta:Bumi Aksara

[8] Peraturan Menteri Kesehatan Republik Indonesia Nomor 49 Tahun 2016 Tentang Pedoman Teknis Pengorganisasian Dinas Kesehatan Provinsi Dan Kabupaten/Kota.

[9] Peraturan Menteri Kesehatan Republik Indonesia Nomor 54 Tahun 2017 Tentang Penanggulangan Pemasungan dengan Orang Dengan Gangguan Jiwa.

[10] Rasyid, Muhammad Yahya. 1997. Makna Pemerintahan : Tinjauan dari Segi Etika dan Kepemimpinan. Jakarta. Yarsif Watampone

[11] Riyadi, Sujono \& Purwanto, Teguh. 2009. Asuhan Keperwata Jiwa. Yogyakarta : Graha Ilmu

[12] Satiri,Djam'an dan Komariah,Aan,2014. Metodologi Penelitian Kualitatif Bandung, Cv Alfabeta

[13] Simanjuntak, Julianto.2008. Konseling Gangguan Jiwa \& Okultisme. Jakarta : Gramedia Pustaka Utama

[14] Siswanto. 2007. Kesehatan mental,konsep, cakupan dan perkembanganya. Yogyakarta : Andi 
[15] Sugiyono. 2013. Metode Penelitian Kuantitatif, Kualitatif, dan R\&D. Bandung:Alfabeta.

[16] Undang-Undang Dasar Negara Republik Indonesia Tahun 1945

[17] Undang-Undang Republik Indonesia Nomor 18 Tahun 2014 Tentang Kesehatan Jiwa

[18] Undang-undang Republik Indonesia Nomor 36 Tahun 2009 tentang Kesehatan

[19] Undang-undang Republik Indonesia Nomor 39 Tahun 1999 Tentang Hak Asasi Manusia 